\title{
Efficacy and tolerability of mexiletine treatment in patients with recurrent ventricular tachyarrhythmias and implantable cardioverter-defibrillator shocks
}

\author{
Marcin Sobiech*, Michał Lewandowski ${ }^{*}$, Dariusz Zając, Aleksander Maciąg, Paweł Syska, \\ Joanna Ateńska-Pawłowska, Ilona Kowalik, Maciej Sterliński, Hanna Szwed, Mariusz Pytkowski \\ $2^{\text {nd }}$ Department of Coronary Artery Disease, Institute of Cardiology, Warsaw, Poland \\ "Authors equally contributed to this work and may be considered as "first authors".
}

\begin{abstract}
A b stract
Background: Antiarrhythmic treatment of patients with recurrent ventricular tachyarrhythmia, in whom catheter ablation and amiodarone treatment were ineffective or contraindicated, is an unsolved clinical problem.

Aim: The study aims to evaluate the efficacy and tolerability of mexiletine in patients with recurrent ventricular tachyarrhythmias and/or electrical storm events, in whom standard treatment strategies failed to prevent ventricular tachyarrhythmia.

Methods: We performed a retrospective cohort analysis of all patients treated with mexiletine for recurrent ventricular tachycardia and/or ventricular fibrillation in our institution between January 2011 and September 2015. The primary endpoints were total number of electrical storm events and ventricular tachycardia/ventricular fibrillation (VT/VF) episodes after the beginning of mexiletine therapy. Secondary endpoints were total number of implantable cardioverter-defibrillator (ICD) therapies and discontinuation of the therapy. Events were compared with a matched duration period before initiating mexiletine. Patients served as self-controls.

Results: Seventeen patients were included in the study; 11 patients were males. Mean age was $64.2 \pm 15.4$ years. The median time of mexiletine treatment was eight months (interquartile range [IR]: 1-22 months). The mexiletine dose was $600 \mathrm{mg} / \mathrm{day}$ in 13 patients and $400 \mathrm{mg} /$ day in four patients. In four patients the dose was modified during treatment in a range from 400 to $600 \mathrm{mg} /$ day depending on clinical decision. Treatment with mexiletine significantly reduced the number of electrical storm events (14 episodes vs. two episodes; median and IR for 17 patients: 1 [0-1] vs. 0 [0-0], p = 0.0010), VT/VF episodes (285 vs. 74 episodes; median and IR for 17 patients: 7 [5-27] vs. 0 [0-5], p =0.0115), and ICD interventions (317 interventions vs. nine interventions; median and IR for 17 patients: 10 [5-25] vs. 0 [0-2], p = 0.0006), in comparison with a matched period before initiation of treatment. In 14 out of 17 patients (82\%) sufficient tolerability of mexiletine was observed. Only in three (18\%) patients severe side effects of mexiletine treatment occurred requiring discontinuation of therapy.

Conclusions: Mexiletine was a sufficiently tolerated antiarrhythmic drug in short-term treatment of ventricular tachyarrhythmias in the studied population. Mexiletine may be effective in the treatment of recurring ventricular tachyarrhythmias or electrical storm events.
\end{abstract}

Key words: electrical storm, implantable defibrillator, mexiletine, ventricular tachyarrhythmia

Kardiol Pol 2017; 75, 10: 1027-1032

\section{INTRODUCTION}

Antiarrhythmic treatment of patients with recurrent ventricular tachyarrhythmia, in whom catheter ablation and amiodarone treatment were ineffective or contraindicated, is an unsolved clinical problem. Patients with cardioverter-defibrillator (ICD) implanted constitute the high-risk population of recurrent ventricular tachycardia or ventricular fibrillation (VT/VF) episodes. In these patients repeated ICD discharges can occur, including electrical storm events. Frequent ICD discharges are associated with worse clinical outcome and decreased

Address for correspondence:

Marcin Sobiech, MD, $2^{\text {nd }}$ Department of Coronary Artery Disease, Institute of Cardiology, ul. Spartańska 1, 02-637 Warszawa, Poland, e-mail: marcinsobiech@wp.pl Received: 07.02.2017 Accepted: 01.06.2017

Kardiologia Polska Copyright (C) Polskie Towarzystwo Kardiologiczne 2017 
quality of life [1, 2]. Furthermore, electrical storm events and their recurrence represent a life-threatening condition. Antiarrhythmic drugs are the usual initial treatment, followed by catheter ablation [3]. When radiofrequency ablation (RFA) is not feasible or not readily available and treatment with beta-adrenolytics and amiodarone is ineffective, mexiletine could be an important therapeutic option in decreasing the recurrence of electrical storm events, ventricular tachyarrhythmia, and ICD discharges. This study aimed to evaluate the efficacy and tolerability of mexiletine in patients with recurrent ventricular tachyarrhythmias and/or electrical storm events, in whom standard treatment strategies failed.

\section{METHODS}

\section{Patient selection}

We performed a retrospective cohort analysis of all patients treated with mexiletine for recurrent VT/VF in our institution between January 2011 and September 2015. All except one patient had an ICD implanted. One patient refused ICD implantation. We analysed patients' medical records, updated on routine follow-up visits, and ICD interrogation.

\section{Indication for mexiletine treatment}

In 12 patients mexiletine treatment was started after the episode of electrical storm (three or more separate episodes of VT/VF demanding ICD discharge in a period of $24 \mathrm{~h}$ ). In five patients mexiletine was administrated due to numerous recurrent VT/VF that did not fulfil criteria for electrical storm. In the studied group standard pharmacological treatment and/or RFA did not prevent the occurrence of ventricular tachyarrhythmia. Mexiletine treatment was indicated in three groups of patients: 1) in patients with previous history of unsuccessful treatment with RFA and optimal medical therapy (including amiodarone if feasible) not qualified to next RFA; 2 ) in patients previously not treated with RFA, awaiting the procedure, in whom primarily lidocaine efficacy followed by mexiletine efficacy was proven in in-hospital condition; 3) in patients unsuccessfully treated with optimal medical therapy, without history of previous RFA, and not qualified to ablation procedures due to contraindications.

\section{Antiarrhythmic therapy}

Every patient before starting mexiletine treatment was treated unsuccessfully with other antiarrhythmic drugs or side effects occurred. All patients were treated with beta-adrenolytic drugs in maximal tolerable dose, and this treatment was continued after mexiletine was started. The attempt of amiodarone treatment was made in 15 out of 17 patients (88\%). When treatment with amiodarone was unsuccessful or side effects and intolerance of treatment occurred, the drug was discontinued. Depending on underlying disease, optimal medical therapy was administrated.

\section{Catheter radiofrequency ablation}

Catheter RFA of ventricular tachyarrhythmia was considered in every patient included in the study. Ablation was finally performed in 12 out of 17 patients (70\%). In seven out of 12 patients, ablation was performed before mexiletine treatment was started, in four patients during treatment with mexiletine, and in one patient after unsuccessful mexiletine treatment. In four out of five patients in whom mexiletine was started before RFA the drug was not continued after the procedure. Only one patient with a history of two previous unsuccessful RFAs treatment with mexiletine was continued after the subsequent ablation procedure.

Five patients were not qualified to RFA: three patients because of high risk of procedure, one patient because of severe symptoms of heart failure, and one patient because of electrical storm due to reversible cause in a course of acute coronary syndrome treated successfully with percutaneous coronary intervention (PCI).

\section{ICD programming}

Detection zones and arrhythmia therapy programming in patients with ICD (16 out of 17 patients) was individualised. Two and three detection zones were programmed in six and nine patients, respectively. One patient was programmed with one zone. Average VT detection zone was 165 bpm (distribution 136-200 bpm) and 221 bpm (distribution 200-250 bpm) for VF detection zone. During mexiletine therapy detection zones were reprogrammed in four patients due to particular ventricular tachyarrhythmia occurrence. Mexiletine treatment itself was not an indication for detection zone reprogramming.

\section{Study endpoints}

The primary endpoints were total number of VT/VF episodes and electrical storm events after beginning mexiletine therapy. Secondary endpoints were total number of ICD therapies and discontinuation of therapy. The events while on mexiletine treatment were compared with a matched duration period just before initiation of mexiletine. The study was approved by the Local Ethics Committee.

\section{Statistical analyses}

Numerical variables were presented as arithmetic mean values with standard deviation when normally distributed or as median with interquartile range for non-normal distributions. Significance of differences was verified with paired Student's t-test or Wilcoxon's rank sum paired test, as appropriate. Categorical variables were expressed as absolute or relative frequency. Comparison of them was performed using $\chi^{2}$ test, or in cases of a minimum expected count less than five, the Fisher exact test. Differences in event-free survival over time were analysed by the Kaplan-Meier method. The log-rank test was used to compare the survival curves. P-values 
Table 1. Baseline clinical characteristics

\begin{tabular}{|lc|}
\hline Underlying heart disease: & $11(64.7 \%)$ \\
CAD & $6(35.3 \%)$ \\
Non-CAD: & 2 \\
DCM & 1 \\
Heart sarcoidosis & 1 \\
ARVC & 1 \\
LQTS & 1 \\
Idiopathic VF & $29.4 \pm 15.4$ \\
LVEF [\%] (mean, range) & $2 / 9 / 5 / 1$ \\
NYHA class: I/I/III/IV & $12 / 4 / 1$ \\
ICD/CRT-D/PM & \\
Prophylaxis: & $5(29.4 \%)$ \\
Primary & $11(64.7 \%)$ \\
Secondary & \\
Concomitant diseases: & $11(64.7 \%)$ \\
Hypertension & $13(76.5 \%)$ \\
Hyperlipidaemia & $5(29.4 \%)$ \\
Diabetes mellitus & $9(52.9 \%)$ \\
Atrial fibrillation & $5(29.4 \%)$ \\
Chronic kidney disease & $1(5.9 \%)$ \\
COPD & \\
\hline
\end{tabular}

Data are presented as number (percentage) of patients; ARVC arrhythmogenic right ventricular cardiomyopathy; CAD — coronary artery disease; COPD - chronic obstructive pulmonary disease; CRT-D — cardiac resynchronisation therapy-defibrillator; ICD — implantable cardioverter-defibrillator; LVEF — left ventricular ejection fraction; LQTS — long QT syndrome; NYHA — New York Heart Association; $\mathrm{PM}$ - pacemaker; VF — ventricular fibrillation

Table 2. Pharmacological treatment

\begin{tabular}{|lc|}
\hline ANTIARRHYTHMIC DRUGS & \\
Beta-adrenolytics: & $17(100 \%)$ \\
$\quad$ bisoprolol (mean dose $8.33 \mathrm{mg} /$ day) & 9 \\
carvedilol (mean dose $45.5 \mathrm{mg} /$ day) & 3 \\
metoprolol (mean dose $58.33 \mathrm{mg} /$ day) & 3 \\
$\quad$ propranolol (mean dose $210 \mathrm{mg} /$ day) & 2 \\
Amiodarone & $15(88 \%)$ \\
CONCOMITANT MEDICATIONS & \\
ACE-I & $10(58.8 \%)$ \\
ARB & $2(11.8 \%)$ \\
Statins & $13(76.5 \%)$ \\
ASA & $12(70.6 \%)$ \\
Eplerenone/spironolactone & $8 / 6(82.4 \%)$ \\
VKANNOAC & $4 / 3(41.2 \%)$ \\
\hline
\end{tabular}

Data are presented as number (percentage) of patients; ACE-I — angiotensin converting enzyme inhibitor; ARB - angiotensin II receptor blocker; ASA — acetylsalicylic acid; NOAC — non-vitamin K oral anticoagulant; VKA — vitamin $\mathrm{K}$ antagonist from two-sided tests of $<0.05$ were considered statistically significant. Statistical analysis was performed with SAS 9.2 (SAS Institute Inc., Cary NC, USA) software.

\section{RESULTS}

Seventeen patients were included in the study; 11 patients were males. Mean age was $64.2 \pm 15.4$ years. The median time of mexiletine treatment was eight months (interquartile range [IR]: 1-22 months). The starting dose of mexiletine was $600 \mathrm{mg} /$ day in 13 patients and $400 \mathrm{mg} /$ day in four patients. In these four patients, the dose was modified during treatment in a range from 400 to $600 \mathrm{mg} /$ day because of weak drug tolerance. Baseline clinical characteristics of the studied group are presented in Table 1 and concomitant pharmacological treatment in Table 2.

\section{Efficacy of mexiletine treatment}

Efficacy of mexiletine treatment was evaluated by comparing recurrence of electrical storm events, incidence of VT/VF, and number of ICD interventions during mexiletine treatment with the same period of time directly before initiation of mexiletine (Table 3).

\section{Tolerability and safety of mexiletine treatment}

Mexiletine tolerability without notable side effects was observed in 10 (58.8\%) patients. In four (23.5\%) patients, mild temporary side effects were observed, which did not require discontinuation of therapy (in two patients temporary and mild abdominal pain, in one patient extremities tremor, in one patient dizziness). Therefore, in 14 out of 17 patients $(82.4 \%)$ a sufficient tolerability of mexiletine was observed. Only in three (17.6\%) patients severe side effects of mexiletine treatment occurred requiring discontinuation of treatment (in two patients severe abdominal pain, in one patient severe dizziness). All side effects of mexiletine treatment occurred during several days after initiation of therapy. No deaths were observed during mexiletine therapy.

\section{DISCUSSION}

In most clinical studies, recurrence of ventricular tachyarrhythmias in ICD patients appear in 20-30\%. This percentage is even higher in secondary prevention [1, 2]. In acute phase, especially in the case of electrical storm event, it is important to treat and exclude reversible causes such as acute coronary syndrome, myocardial ischaemia, or electrolyte abnormalities. Sedative drugs are especially helpful in terminating ventricular tachyarrhythmias and recurrence of ICD discharges. Antiarrhythmic drugs are the usual long-term treatment strategy, and in most patients amiodarone is chosen in the first line. Although amiodarone or sotalol may reduce ventricular tachyarrhythmias, they are often ineffective or may not be tolerated $[4,5]$.

Current clinical guidelines recommend catheter ablation as the treatment of choice in patients after electrical storm 
Table 3. Ventricular tachyarrhythmias and implantable cardioverter-defibrillator (ICD) interventions before and after mexiletine introduction

\begin{tabular}{|c|c|c|c|c|}
\hline $\begin{array}{l}\text { Ventricular tachyarrhythmias } \\
\text { and ICD interventions }\end{array}$ & & $\begin{array}{l}\text { Before mexiletine } \\
\text { introduction }\end{array}$ & $\begin{array}{l}\text { After mexiletine } \\
\text { introduction }\end{array}$ & $\mathbf{P}$ \\
\hline \multirow[t]{4}{*}{ Electrical storm events } & Number of patients & $12(70.6 \%)$ & $2(11.8 \%)$ & 0.0005 \\
\hline & Number of episodes & 14 episodes & 2 episodes & 0.0010 \\
\hline & Median [IR] & For all 17 patients: 1 [0-1] & For all 17 patients: 0 [0-0] & \\
\hline & & $\begin{array}{l}\text { For } 12 \text { patients with } \\
\text { electrical storm: } 1 \text { [1-1] }\end{array}$ & $\begin{array}{l}\text { For } 2 \text { patients with } \\
\text { electrical storm: } 1 \text { [1-1] }\end{array}$ & 1.000 \\
\hline \multirow[t]{4}{*}{ VT/NF episodes } & Number of patients & $17(100 \%)$ & $6(35.3 \%)$ & $<0.0001$ \\
\hline & Number of episodes & 285 episodes & 74 episodes & 0.0115 \\
\hline & Median [IR] & For all 17 patients: 7 [5-27] & For all 17 patients: 0 [0-5] & \\
\hline & & $\begin{array}{l}\text { For } 17 \text { patients with VT/VF } \\
\text { episodes: } 7 \text { [5-27] }\end{array}$ & $\begin{array}{l}\text { For } 6 \text { patients with VT/NF } \\
\text { episodes: } 8 \text { [5-61] }\end{array}$ & 0.8125 \\
\hline \multirow[t]{4}{*}{ ICD interventions (HV + ATP) } & Number of patients & $16(94.1 \%)$ & $5(29.4 \%)$ & $<0.0001$ \\
\hline & Number of interventions & 317 interventions & 9 interventions & 0.0006 \\
\hline & Median [IR] & For all 16 patients: 10 [5.5-25] & For all 16 patients: 0 [0-2] & \\
\hline & & $\begin{array}{c}\text { For } 16 \text { with ICD } \\
\text { interventions: } 10 \text { [5.5-25] }\end{array}$ & $\begin{array}{l}\text { For } 5 \text { patients with ICD } \\
\text { interventions: } 4 \text { [3-13] }\end{array}$ & 0.3125 \\
\hline
\end{tabular}

Data are presented as number (percentage) of patients and median with interquartile range (median [IR]); $\mathrm{p}$-values of $<0.05$ were considered statistically significant; ATP — anti-tachycardia pacing; HV — high voltage therapy; VT/NF — ventricular tachycardia/ventricular fibrillation

events (level of evidence IB), whereas after the first episode of VT/VF with ICD intervention RFA should be considered (level of evidence IIA) [3]. However, efficacy of this treatment is limited [6, 7]. In our study recurrence of ventricular tachyarrhythmias in seven patients with history of RFA before treatment with mexiletine occurred after an average of five months (range from one to 16 months).

Some patients require repeated procedures carrying higher risk of potential complications. Other patients may have contraindications to RFA or amiodarone. What is more, serious complications of amiodarone may occur during treatment, which limits its use. In a study comparing treatment of amiodarone with ICD pulmonary toxicity was suspected in $3 \%$ of the patients treated with amiodarone at one year and $5 \%$ at two years. Thyroid replacement medication was prescribed for $10 \%$ of the patients treated with amiodarone by one year and $16 \%$ by two years [2]. Almost $40 \%$ of patients treated with amiodarone discontinue medication in median follow-up of 21 months. The most common causes of discontinuation are thyroid abnormalities, followed by pulmonary and gastrointestinal disorders [8].

In our study, previous amiodarone treatment was present in 15 (88\%) patients, but 11 of them (73\%) required discontinuation of therapy. Amiodarone was not started in two young patients, due to possible long-term complications. Only three patients continued concomitant treatment with amiodarone and mexiletine. The most frequent reasons for discontinuation of amiodarone were thyroid complications (seven out of 11 patients, 64\%), inefficacy of treatment (two patients), early intolerance (one patient), and ophthalmic complications (one patient).

Data concerning the efficacy of mexiletine in patients with ICD and recurrent VT is limited. Mexiletine successfully reduced the number of premature ventricular contractions as well as VT, without compromising ejection fraction of left ventricle in some studies [9, 10]. Despite these findings caution should be taken during mexiletine treatment in patients with decreased ejection fraction, and this requires further studies. In our study, treatment with mexiletine was preceded by unsuccessful optimal medical therapy and/or RFA. Dongsheng Gao et al. [11] proved that in patients in whom treatment with amiodarone was unsuccessful, adding mexiletine reduced number of VT and ICD shocks, but only in a short-term observation. The efficacy of mexiletine decreased relevantly in 12-month observation.

In our study, treatment with mexiletine significantly reduced the number of electrical storm events (14 episodes vs. two episodes; median and IR for 17 patients: 1 [0-1] vs. 0 [0-0], $p=0.0010)$, VT/VF episodes (285 vs. 74 episodes; median and IR for 17 patients: 7 [5-27] vs. 0 [0-5], $p=0.0115$ ), and ICD interventions (317 interventions vs. nine interventions; median and IR for 17 patients: 10 [5-25] vs. 0 [0-2], $p=0.0006]$, in comparison with a matched period before initiation of treatment.

In the majority of patients mexiletine was used in a short-term period. In five patients it was used as a "bridging therapy" after successful treatment with intravenous lidocaine in acute phase, showing good short-term efficacy until the 
time of RFA. In these patients the average time between introduction of mexiletine treatment and RFA procedure was 3.2 months (range from one to eight months).

The presented study also proves that mexiletine treatment could be continued in the long term. The average treatment period with mexiletine was eight months (IR 1-22 months), but six patients were treated for longer than 12 months, and in one patient treatment could be continued for up to 57 months successfully.

Mexiletine, together with ICD implantation and beta-adrenolytic therapy, potentially could be used in the long term in patients with distinct genetically mediated channelopathies, including long QT syndrome (LQTS). In patients with LQTS type 3 (LQTS 3), blocking late sodium current $\left(I_{N_{a}}\right)$ in phase 0 and 1 of the activation potential mexiletine shortens the QT interval, decreases dispersion of repolarisation between epi- and endocardium, and as a result diminishes recurrence of polymorphic VT [12]. In experimental studies mexiletine also decreased dispersion of repolarisation in LQTS type 1 and 2 (LQTS 1, LQTS 2) as well as reducing the number of ventricular tachyarrhythmias in case studies of patients with Andersen-Tawil syndrome [13] and Timothy syndrome [14].

In our study, we present a case of long-term efficacy of mexiletine treatment in a patient with LQTS and recurrent polymorphic VT and VF with frequent ICD shocks (including VT storm) as well as a case of over three years' efficacy in a patient with idiopathic VF and numerous ICD interventions before initiation of mexiletine therapy.

Our study is concordant with previous studies showing that treatment with mexiletine is safe and sufficiently tolerated [8-11]. The percentage of patients with mexiletine intolerance was low (18\%).

The study indicates that treatment with mexiletine may be effective and safe in patients with ICD and frequent ventricular arrhythmias and ICD shocks, regardless of the aetiology of heart disease.

Unfortunately, in some European countries, including Poland, mexiletine is not readily available on the market. In Poland, the necessity of drug import with time-consuming formal procedures limits its use.

\section{Limitations of the study}

It was a small single-centre retrospective cohort study, with a heterogeneous group of patients and no control group. The natural course of VT/VF events, reprograming of detection zones of ICD, and use of concomitant pharmacotherapy and RFA may have contributed to the occurrence of events after mexiletine introduction.

\section{CONCLUSIONS}

1. Mexiletine is a sufficiently tolerated antiarrhythmic drug in short-term treatment of ventricular tachyarrhythmias in the studied population.

2. Mexiletine may be effective in the treatment of recurring ventricular tachyarrhythmias or electrical storm events.

\section{Conflict of interest: none declared}

\section{References}

1. Moss AJ, Zareba W, Hall WJ, et al. Prophylactic implantation of a defibrillator in patients with myocardial infarction and reduced ejection fraction. Multicenter Automatic Defibryllator Implantation Trial - II (MADIT II). N Engl J Med. 2002; 346(12): 877-883, doi: 10.1056/NEJMoa013474, indexed in Pubmed: 11907286.

2. Antiarrhythmics versus Implantable Defibrillators (AVID) Investigators. A comparison of antiarrhythmic-drug therapy with implantable defibrillators in patients resuscitated from near-fatal ventricular arrhythmias. N Engl J Med. 1997; 337(22): 1576-1583, doi: 10.1056/NEJM199711273372202, indexed in Pubmed: 9411221.

3. Priori SG, Blomström-Lundqvist C, Mazzanti A, et al. 2015 ESC Guidelines for the management of patients with ventricular arrhythmias and the prevention of sudden cardiac death: The Task Force for the Management of Patients with Ventricular Arrhythmias and the Prevention of Sudden Cardiac Death of the European Society of Cardiology (ESC). Endorsed by: Association for European Paediatric and Congenital Cardiology (AEPC). Eur Heart J. 2015; 36(41): 2793-2867, doi: 10.1093/eurheartj/ehv316, indexed in Pubmed: 26320108.

4. Connolly SJ, Dorian P, Roberts RS, et al. Comparison of beta-blockers, amiodarone plus beta-blockers, or sotalol for prevention of shocks from implantable cardioverter defibrillators: the OPTIC Study: a randomized trial. JAMA. 2006; 295(2): 165-171, doi: 10.1001/jama.295.2.165, indexed in Pubmed: 16403928.

5. Pacifico A, Hohnloser $\mathrm{SH}$, Williams JH, et al Prevention of implantable-defibrillator shocks by treatment with sotalol. d,l-Sotalol Implantable Cardioverter-Defibrillator Study Group. N Engl J Med. 1999; 340(24): 1855-1862, doi: 10.1056/NEJM199906173402402, indexed in Pubmed: 10369848.

6. Donateo P, Bottoni N, Oddone D, et al. Long-Term results after single and multiple procedures of ablation of ventricular tachycardia. J Cardiovasc Electrophysiol. 2016; 27(11): 1319-1324, doi: 10.1111/jce.13061.

7. Kumar S, Romero J, Mehta NK, et al. Long-term outcomes after catheter ablation of ventricular tachycardia in patients with and without structural heart disease. Heart Rhythm. 2016; 13(10): 1957-1963, doi: 10.1016/j. hrthm.2016.07.001, indexed in Pubmed: 27392945

8. Julian DG, Camm AJ, Frangin G, et al. Randomised trial of effect of amiodarone on mortality in patients with left-ventricular dysfunction after recent myocardial infarction: EMIAT. European Myocardial Infarct Amiodarone Trial Investigators. Lancet. 1997; 349(9053): 667-674 [Erratum, Lancet 1997;349:1180.], indexed in Pubmed: 9078197.

9. Rutledge J, Harris F, Amsterdam E. Clinical evaluation of oral mexiletine therapy in the treatment of ventricular arrhythmias. Journal of the American College of Cardiology. 1985; 6(4): 780-784, doi: 10.1016/s07351097(85)80482-4.

10. Campbell NP, Pantridge JF, Adgey AA. Long-term oral antiarrhythmic therapy with mexiletine. Br Heart J. 1978; 40(7): 796-801, indexed in Pubmed: 687477.

11. Gao D, Herendael HV, Alshengeiti L, et al. Mexiletine as an Adjunctive Therapy to Amiodarone Reduces the Frequency of Ventricular Tachyarrhythmia Events in Patients With an Implantable Defibrillator. J Cardiovasc Pharmacol. 2013; 62(2): 199-204, doi: 10.1097/fjc.0b013e31829651fe

12. Mazzanti A, Maragna R, Faragli A, et al. Gene-Specific therapy with mexiletine reduces arrhythmic events in patients with long QT syndrome type 3. J Am Coll Cardiol. 2016; 67(9): 1053-1058, doi:10.1016/j.jacc.2015.12.033.

13. Garcia-Touchard A, Somers VK, Kara T, et al. Ventricular ectopy during REM sleep: implications for nocturnal sudden cardiac death. Nat Clin Pract Cardiovasc Med. 2007; 4(5): 284-288, doi: 10.1038/ncpcardio0877, indexed in Pubmed: 17457352.

14. Li G, Xue X, Han W, et al. GW26-e1798 Successful Treatment of a LQT8 Case with Mexiletine: 4 years of experience. J Am Coll Cardiol. 2015; 66(16): C176-C177, doi: 10.1016/j.jacc.2015.06.675.

Cite this article as: Sobiech M, Lewandowski M, Zając D, et al. Efficacy and tolerability of mexiletine treatment in patients with recurrent ventricular tachyarrhythmias and implantable cardioverter-defibrillator shocks. Kardiol Pol. 2017; 75(10): 1027-1032, doi: 10.5603/KP.2017.0189. 


\title{
Skuteczność i tolerancja leczenia mexiletyną pacjentów z nawracającymi tachyarytmiami komorowymi i wyładowaniami implantowanego kardiowertera-defibrylatora
}

\author{
Marcin Sobiech*, Michał Lewandowski ${ }^{*}$, Dariusz Zając, Aleksander Maciąg, Paweł Syska, \\ Joanna Ateńska-Pawłowska, Ilona Kowalik, Maciej Sterliński, Hanna Szwed, Mariusz Pytkowski \\ II Klinika Choroby Wieńcowej, Instytut Kardiologii, Warszawa \\ *Autorzy w równym stopniu przyczynili się do powstania niniejszej pracy i mogą być traktowani jako jej pierwsi autorzy.
}

\section{Streszczenie}

Wstęp: Leczenie antyarytmiczne pacjentów z nawracającymi złożonymi komorowymi zaburzeniami rytmu serca, u których ablacja prądem o wysokiej częstotliwości lub amiodaron okazały się nieskuteczne lub są przeciwskazane, stanowi istotny problem kliniczny.

Cel: Badanie ma na celu ocenę skuteczności i tolerancji leczenia mexiletyną u pacjentów z nawracającymi komorowymi zaburzeniami rytmu serca i/lub incydentami burzy elektrycznej, u których standardowe strategie terapeutyczne okazały się nieskuteczne w zapobieganiu ich nawrotom.

Metody: Dokonano retrospektywnej analizy wszystkich pacjentów leczonych mexiletyną z powodu nawracających częstoskurczów komorowych i/lub migotań komór (VT/VF) między styczniem 2011 roku a wrześniem 2015 roku w ośrodku, w którym pracują autorzy niniejszej pracy. Pierwszorzędowy punkt końcowy badania stanowiła całkowita liczba epizodów burzy elektrycznej oraz epizodów VT/VF po włączeniu leczenia mexiletyną. Drugorzędowe punkty końcowe stanowiły: całkowita liczba terapii za pomocą implantowanego kardiowertera-defibrylatora (ICD) w trackie leczenia mexiletyną oraz odsetek zaprzestania terapii mexiletyną. Zdarzenia określane jako punkty końcowe w trakcie terapii mexiletyną porównywano z analogicznym okresem przed zastosowaniem leku.

Wyniki: Do badania włączono 17 pacjentów, w tym 11 mężczyzn. Średni wiek chorych wynosił 64,2 \pm 15,4 roku, a średni czas leczenia mexiletyną — 8 miesięcy (przedział międzykwartylowy [IR]: 1-22 miesięcy). Dawka dobowa mexiletyny wyniosła 600 mg u 13 pacjentów oraz 400 mg u 4 pacjentów. U 4 osób dawka mexiletyny była modyfikowana w trakcie terapii w zakresie od 400 do 600 mg na dobę, w zależności od sytuacji klinicznej. Leczenie mexiletyną spowodowało istotną redukcję epizodów burzy elektrycznej (14 epizodów vs. 2 epizody; średnia oraz IR dla 17 pacjentów: 1 [0-1] vs. 0 [0-0]; $p=0,0010$ ), epizodów VT/VF (285 vs. 74 epizody; średnia oraz IR dla 17 pacjentów: 7 [5-27] vs. 0 [0-5]; $p=0,0115]$ oraz interwencji ICD (317 vs. 9 interwencji; średnia oraz IR dla 17 pacjentów: 10 [5-25] vs. 0 (0-2); p =0,0006) w porównaniu z analogicznym okresem przed włączeniem leku. U 14 z 17 chorych (82\%) zaobserwowano zadowalającą tolerancję leczenia mexiletyną. Tylko u 3 (18\%) osób wystąpiły nasilone objawy uboczne wymagające odstawienia leku.

Wnioski: Mexiletyna jest bezpiecznym i zadowalająco tolerowanym lekiem antyarytmicznym w terapii złożonych komorowych zaburzeń rytmu serca w badanej populacji w okresie krótkoterminowym. Leczenie mexiletyną pacjentów z nawracającymi częstoskurczami komorowymi i epizodami burzy elektrycznej może być skuteczne w zapobieganiu jej nawrotom.

Słowa kluczowe: burza elektryczna, implantowany kardiowerter-defibrylator, mexiletyna, komorowe zaburzenia rytmu serca Kardiol Pol 2017; 75, 10: 1027-1032 